\title{
ValpoScholar
}

Valparaiso University Law Review

Volume 20

Number 3 Spring 1986

pp.385-411

Spring 1986

\section{Opening Hart's Concept of Law}

Richard K. Sherwin

Follow this and additional works at: https://scholar.valpo.edu/vulr

Part of the Law Commons

\section{Recommended Citation}

Richard K. Sherwin, Opening Hart's Concept of Law, 20 Val. U. L. Rev. 385 (1986).

Available at: https://scholar.valpo.edu/vulr/vol20/iss3/1

This Article is brought to you for free and open access by the Valparaiso University Law School at ValpoScholar. It has been accepted for inclusion in Valparaiso University Law Review by an authorized administrator of ValpoScholar. For more information, please contact a ValpoScholar staff member at scholar@valpo.edu. 


\title{
Valparaiso University Law Review
}

\begin{tabular}{lll}
\hline \hline Volume 20 & Spring 1986 & Number 3 \\
\hline \hline
\end{tabular}

\section{OPENING HART'S CONCEPT OF LAW}

\author{
RICHARD K. SHERWIN*
}

The truths which are ultimately accepted as the first principles of a science are really the last result of metaphysical analysis practiced on the elementary notions with which the science is conversant; and their relation to the science is not that of foundations to an edifice, but of roots to a tree, which may perform their office equally well though they be never dug down to and exposed to light.

J.S. Mill, Utilitarianism

\section{INTRODUCTION}

It has been said that philosophy is a quest for the "beginnings" of things. ${ }^{1}$ In our psychological age, ${ }^{2}$ it may not be surprising to discover that originary images of man confront the philosopher's backward glance. Yet, the changes in such images from classical to modern times are not without a curious irony. For from Aristotle's grounding of ethical theory in the final good embodied in man's transcendent nature, ${ }^{3}$ we rudely encounter Hobbes' hard, modern vision. In the Hobbesian psychology, man is riddled by fear of violent death and ruled by an unquenchable passion to dominate his fellows. ${ }^{4}$

* Instructor in Law, New York University School of Law.

1. L. Strauss, Natural Right ani) History 83 (1953).

2. For a sample of the broad range of psychological theorizing that appears in contemporary legal discourse, see J. RAwLS, A THEORY of JusTICE 459-96 (1971) (citing Piaget's developmental psychology to account for innate moral intelligence); R. Unger, KNoWledge AND Politics 21-62 (1975) (discussing the liberal model of the self in order to expose its internal contradictions); T. SHAFFER \& R. REDMOUNT, Lawyers, Law Students and People 209-29 (1977) (using insights derived from Rogerian psychology to argue for a more "humanistic" approach to legal education).

3. See Aristotle, Nichomachean Ethics, in Introduction to ArIStotle 532 (Book X, ch. 7) (R. McKeon ed. 1947) ("The good of man is an activity of the soul in conformity with excellence or virtue." According to Aristotle, the highest virtue is that of "the best thing in us" which may be "reason" and "also divine" or "only the most divine element in us."). See also Irwin, The Metaphysical and Psychological Batsis of Aristotle's Ethics, in Essays on ARISTOTLE's Ethics 48-50 (A. Rorty ed. 1980); Nagle, Aristolle on Eudaimonia, in Essays on ARISTOTLE's ETHICs 13 (A. Rorty ed. 1980).

4. T. Hobbes, Leviathan 447 (M. Oakeshott ed. 1960) ("' $[\mathrm{I}] \mathrm{t}$ is men, and arms, not words and promises, that make the force and power of the laws."). 
The break with classical faith in nature (including human nature) is clean.

According to Hobbes, given the natural state of "war of every one against everyone,"5 only an absolute, coercive power can maintain the peaceable order that survival requires. Thus, humans may win peace only by submitting to a compulsion which, though set up by themselves, still remains an irrevocably external force.

Rousseau later pushed the modern transformation of man further. Corrupted human nature could now be made over by political power. Humans could become moral in accordance with the natural order established by political society. Thus, with Rousseau, Hobbes' dark vision is converted to light. The absolute power of the Hobbesian sovereign is now to be realized in the will of the collective. The once wholly external coercive sanctions now become wholly internalized. It is against this backdrop that Rousseau writes: "I can see no viable middle path between the rawest democracy and the most complete Hobbesian system."6

The dilemma expressed by Rousseau has, in one form or another, resounded within jurisprudential thinking down to the present day. On the one hand, we see legal positivists strive to maximize certainty by adverting to objective criteria (or "tests") by which the existence of valid rules may be verified. Characteristically, this attempt involves an external viewpoint based on behavioral observation. Austin's theory of law as commands backed by threats is illustrative of this viewpoint. On the other hand, natural jurists quest for inner moral standards according to which "valid" laws achieve authentic legality. Internalized sanctions and moral properties intrinsic to law itself are characteristic of this viewpoint.

Thus the debate, in large part, proceeds on the basis of the role one assigns to moral theory. The positivist insists that legal obligation may be based on coercive sanctions; law's validity is independent of its moral status. The natural lawyer, by contrast, builds moral theory into his analysis of what legal obligation means. ${ }^{7}$

In The Concept of Law, H.L.A. Hart charts a middle path that seems to go far toward answering Rousseau's dilemma. Hart's con-

5. Id. at $80-83$.

6. 33 J. Rousseau, Correspondence Complete 243 (R. Leigh ed. 1979) (letter to Victor Riquetti, Marquis de Mirabeau, July 26, 1767: "Je ne vois point de milieu supportable entre la plus austére démocratie et le Hobbisme le plus parfait.").

7. Hoffmaster, Professor Hart on Legal Obligation, 11 GA. L. REv. 1303 , 1320-21 (1977); Richards, Rules, Policies and Neutral Principles, 11 GA. L. REv. 1069 (1977). 
ceptual analysis supplies a typology of rules that corrects the inadequacy of Austin's simplistic model of law. Crucial to Hart's notion of social rules is the central role he gives to the "internal viewpoint" which such rules embrace. The internal viewpoint allows Hart to account for internalized normative standards on the basis of which one's own actions and the actions of others may be critically appraised.

One may suggest that Hart's "descriptive sociology" takes his typology of rules further by ultimately grounding their normative content in what Hart calls "natural necessity." This involves those truisms about humans and the world which constitute Hart's "minimum content of natural law." ${ }^{10}$ By virtue of his typology of rules and descriptive sociology, Hart may claim to have preserved the positivist's view of legal validity and the natural lawyer's search for normative standards that ensure the legitimate power or authority of the legal system.

In this essay, I will examine the extent to which Hart's "middle path" may be deemed successful. Specifically, I will appraise The Concept of Law on the basis of the criteria for legitimate power that Hart provides. I will conclude that in their current form Hart's typology of rules and minimum content of natural law do not guarantee the legitimate authority of the legal system. I will suggest, however, that Hart's key insight concerning the internal viewpoint may be broadened so as to rectify this result. Opening Hart's concept of law ${ }^{11}$ to what I will call a normative grammar (not encompassed by Hart's essentially descriptive analysis of legal obligation) is the heart of the extension I will propose. ${ }^{12} \mathrm{~A}$ corresponding shift in the image of man underlying Hart's analysis may also be required..$^{13}$

8. H.L.A. Hart, The Concept of Law v (1961).

9. Id. at 195 .

10. $I d$.

11. By suggesting that Hart's concept of law may be "opened" to embrace more than the definitive and descriptive sets of criteria that Hart provides, I hope to encourage a resonance with Morris Weitz's notion of "open concepts." See M. Weitz, The OPEning Mind x, $4-5$ (1978) (Weitz argues that the absence of necessary and sufficient criteria need not render a concept ambiguous).

12. That legal positivists such as Hart unself-consciously endorse a core of normative tenets (for example, in the form of an unexplained and unsupportedthough not necessarily insupportable-theory of the self) is one of the points this essay seeks to make. A correlative goal is to subject such normative commitments to self-conscious scrutiny so that responsibility for upholding them, including the responsibility to explain and justify them in discourse with others, will not be evaded. Legitimation itself has been viewed as this very process of explaining and justifying. See P. Berger \& T. Luckmann, The Social Construction of Reality 93 (1967).

13. The shift $I$ hint at in this essay involves the move from Hartian descriptive sociology ("this is the way things/people are") (see infra text accompanying notes 48- 
In the first section, I set out the criteria for legitimate power or authority upon which I will be relying in my analysis. I also present the two minimum conditions that Hart regards as both necessary and sufficient for the existence of a mature legal system. In the second section, I examine Hart's typology of rules. I conclude, based on significant ambiguities in Hart's typological analysis, that neither the two minimum conditions nor the criteria for legitimate authority have been met. In the third section, I examine Hart's minimum content of natural law and suggest that it fails to resolve the previously raised difficulties concerning Hartian social rules. In addition, I contend that it also fails to generate a minimum moral content in which to root normative standards that social rules embrace. I conclude that Austin's notion of coercive obligation and Kelsen's claim that law may have any content, contentions firmly rejected by $\mathrm{Hart},{ }^{14}$ are not precluded by Hart's minimum content.

To remedy this difficulty, I offer the extension to which reference already has been made. While the proposed extension lacks refinement, and could benefit greatly from additional critical reflection, I am confident that something like it is necessary to preserve the jurisprudential advance that Hart's proposed "middle path" provides.

\section{The Criteria For Legitimate Power AND THE TWO MiNimuM CONDITIONS}

In The Concept of Law, Hart distinguishes legal from merely coercive obligation. The latter, which Hart associates with Austin's theory of law as commands backed by threats, is rejected by Hart as entirely too simplistic..$^{15}$ As a corrective to Austin's model, Hart proposes his notion of social rules. These rules, by virtue of the internal viewpoint,

55), to an active hermeneutic ("this is the best way to understand the meaning of self, others and events in this particular context, at this particular time"). See infra text accompanying notes 33-36.

Ethics in the Aristotelian sense, as a search for the meaning of virtue, provides a model for normative discourse of the kind I am suggesting. Hermeneutics, understood as the ongoing search for contextualized (i.e., historical) meanings, may provide a way of adapting this Aristotelian model to our largely secularized cultural milieu. Man's freedom, rather than his transcendent nature, now becomes the basis on which ethical reality relies. See W. Luijpen, Phenomenology of Natural Law 213 (1967). See also J. Sartre, Being and Nothingness 60 (H. Barnes trans. 1966) ("Human freedom precedes essence in man and makes it possible; the essence of the human being is suspended in his freedom."); J. White, When Words Lose Their Meaning 175 (1984) (describing the ways in which "[W]e constitute ourselves and our relations with other people when we use, and in using recreate, the language that makes us what we are.").

14. See H.L.A. HART, supra note 8, at 47-48, 203.

15. $I d$. at 26 . 
account for something more than habitual obedience or predictions of behavior-objectively observable phenomena which reflect the response to force that characterizes Austin's jurisprudence. In place of obedience to coercion, (what Hart calls "being obliged"), Hart's model of rules requires voluntary acceptance of authority. ${ }^{16}$

Hart's understanding of social rules, and the central role of the internal viewpoint, will be examined in more detail later on. For the moment, this bare outline may serve to introduce the idea of legitimate power or authority. Authority, in this context, points to a distinction between the factual validity of orders or rules on the one hand, and the belief in their legitimacy or potential for justification on the other. ${ }^{17}$ This notion warrants fuller elucidation. Hart's analysis of Austin's inability to account for rules of succession may serve as a first step.

According to Hart, "being obliged" to obey orders (Austin's habit of obedience) fails to confer any right of succession upon individual rule-makers. Upon the ruler's death there exists no basis for the continuity of command. The habit of obedience enjoyed by the dead ruler (Rex I) no longer exists, and, according to Hart, "it does not even render probable that Rex II will be habitually obeyed." ${ }^{18}$ In short, there is nothing to make Rex II sovereign from the start.

Austin's failure, Hart claims, stems from the fact that habits of obedience do not generate the notion of a rule. ${ }^{19}$ According to Hart, the authority to make rules requires general acceptance of a normative social rule of succession. Because the acceptance of a rule of succession constitutes the existence of that rule, "its acceptance affords ... grounds both for the statement of law that the successor has a right to legislate, even before he starts to do so, and for the statement of fact that he is likely to receive the same obedience as his predecessor does." 20

Put simply, the ruler will not only have a right to rule (based on acceptance of the rule of succession), but it also will be generally accepted that it is right to obey him. The ruler's word will now generate "standards of behavior, not orders."

The criteria for legitimate power may now be stated explicitly. In this regard, I will employ Michael Payne's terms de jure and de

16. Id. at 198 .

17. Id. at 53. For an alternative understanding of forms of legitimation, see 2 M. Weber, Economy and Society 952-54 (G. Roth \& C. Wittich eds. 1978).

18. H.L.A. HART, supra note 8 , at 54 .

19. Id. at 73 .

20. Id. at $57-58$.

21. Id. at 57 . 
facto authority as the constituent elements of legitimate power or authority. ${ }^{22}$ The term de jure authority may be used to describe Rex II's right or title to succeed Rex I. As Payne suggests, to say that someone has de jure authority is to claim that he has a right to do something, and therefore presupposes a system of rules establishing that right. ${ }^{23}$

The term de facto authority may be used to describe a distinctive kind of obedience. Unlike the response to fear, the kind of obedience involved here may roughly be said to involve "respect" or "trust." This type of obedience is to be distinguished from obedience out of fear of punishment (Hart's notion of being obliged) or out of habit. ${ }^{24}$

Notably, a ruler may enjoy de jure authority without also enjoying de facto authority. For example, a ruler may have the de jure right to give orders, but those orders may be obeyed out of fear or habit (in which case he lacks de facto authority). Conversely, de facto authority does not necessitate de jure authority. For example, although unauthorized under a rule of primogeniture, the youngest brother of Rex II may possess the de facto authority that a very unpopular Rex II lacks. ${ }^{25}$

Legitimate power or authority, then, may be used to describe a ruler who possesses both de jure and de facto authority. In Hart's terms, Rex will have the right to specify what is to be done and it will be accepted that it is right to obey him. ${ }^{26}$

With this introduction of the criteria for legitimate power, we have encountered two different types of rules which will require further elucidation. Before taking up that task, however, I would like to present Hart's statement regarding the two minimum conditions which he claims are both necessary and sufficient for the existence of a modern legal system. Hart states:

There are therefore two minimum conditions necessary and sufficient for the existence of a legal system. On the one hand, those rules of behavior which are valid according to the system's ultimate criteria of validity must be generally 302-03 (1976).

22. Payne, Hart's Concept of a Legal System, 18 WM. \& MARY L. Rev. 287,

23. Id. at 302 .

24. Id. at 303 .

25. I I .

26. H.L.A. HART, supra note 8 , at 56-57. 
obeyed, and on the other hand, its rules of recognition specifying the criteria of legal validity and its rules of change and adjudication must be effectively accepted as common public standards of official behavior by its officials. The first condition is the only one which private citizens need satisfy: they may obey 'each for his part only' and from any motive whatever ... the second condition must also be satisfied by the officials of the system. They must regard these as common standards of official behavior and appraise critically their own and each other's deviations as lapses .... The assertion that a legal system exists is therefore a Janus-faced statement looking both towards obedience by ordinary citizens and to the acceptance by officials of secondary rules as critical common standards of official behavior. ${ }^{2 n}$

Hart regards the union of the two types of rules expressed in the foregoing passage as the new "key" to the science of jurisprudence. ${ }^{28} \mathrm{I}$ have quoted this passage at length here because it will serve a critical role in my subsequent analysis of Hart's concept of law. To begin unpacking this statement, I now turn to Hart's typology of rules.

\section{The hartian Typology of Rules}

We have seen in the example of rules of succession that while the Austinian command model of law may account for habits of obedience it fails to generate a notion of rules in the Hartian sense. But what exactly is the Hartian sense? What are social rules? Hart says:

[I] a social rule is to exist, some [members of the social group in question] at least must look on the behavior in question as a general standard to be followed by the group as a whole. A social rule has an internal aspect in addition to the external aspect which it shares with a social habit and which consists in the regular uniform behavior which an observer could record. ${ }^{29}$

Clearly, then, the "internal aspect" is crucial in distinguishing social rules from mere habits of obedience. By the internal viewpoint, (what Hart also calls the 'critical reflective attitude'), Hart is referring to the acceptance of normative standards on the basis of which

27. Id. at 113 .

28. Id. at 79 .

29. Id. at 55 . 
justifiable criticism may be directed toward certain patterns of behavior. ${ }^{30}$ In short, deviation is not only met with pressures for conformity, but it also constitutes of itself a good reason for criticism by others or for self-criticism. ${ }^{31}$ Characteristically, the expression of such criticism is in normative terms, such as "ought," "must," "should," "right" and "wrong."

It has been suggested that the key advance in Hart's concept of social rules consists in his notion of the internal viewpoint, or what MacCormick calls the "hermeneutic" attitude. ${ }^{33}$ "Hermeneutic" in this context refers to the interpretation of judgments from the point of view of the person who passes judgment rather than the person who scrutinizes behavior from the outside. Thus, in order to accept a social rule one must adopt an internal point of view from which normative statements can be made either giving reasons for or justifying certain patterns of behavior or for criticizing that behavior.

A limitation in Hart's analysis may be noted here. Hart fails to account for an understanding of normative standards from the internal point of view that does not actively endorse such standards ${ }^{34}$ It is true, as MacCormick is quick to point out, that for an uncommitted understanding of normative standards to exist an active commitment to such standards on the part of someone or some people must either be postulated or presupposed..$^{35}$ Standing alone, however, Hart's analysis fails to distinguish active from passive acceptance of normative standards..$^{36}$

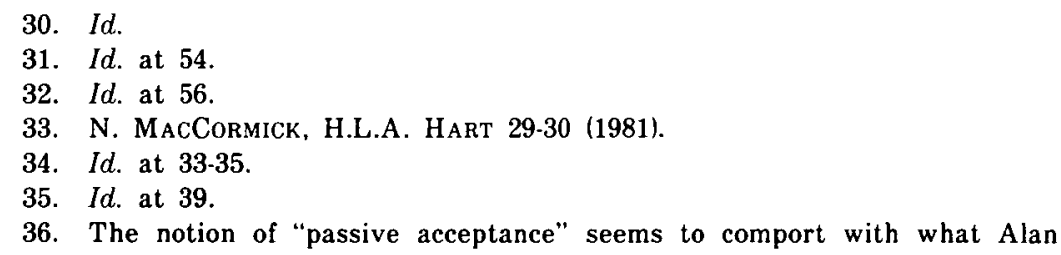
Gibbard has described as being "in the grip of " a norm. See Gibbard, Moral Judgment and the Acceptance of Norms 96 ETHICs 5, 14-17 (Oct. 1985).

According to Gibbard, aside from accepting a norm (as right or reasonable) one may also be compelled by certain "cravings" or "appetites" (such as the felt need to survive) (see infra text accompanying notes 62-65), or by "weakness of will." The latter involves something one may not believe is right to do but which deference to conventional norms of politeness or cooperation may lead one to do. To illustrate this "weakness," Gibbard cites the famous Milgram experiment in which subjects complied with orders to induce (simulated) electric shocks to strangers as part of an "experiment." Two thirds of the subjects complied despite their misgivings about the "wrongness" of their actions. Cf. infra text accompanying note 83 . 
A further difficulty in Hart's analysis stems from his failure clearly to distinguish between "principles" and other "standards" that do not function as "rules." According to Hart, principles, rules and standards "belong to morality and make conduct morally obligatory." 37 But clearly some shared standards or principles are not employed as rules. For example, certain standards of decency are accorded neither the pressure to conformity nor the importance of aims accorded to rules. Nevertheless, standards are often used in conjunction with rules for the purpose of interpreting or critically appraising them. ${ }^{38}$

To make good on Hart's omission in this regard, MacCormick helpfully suggests that principles may be regarded as "rational grounds of conduct" that are "general in their scope." Rules, by contrast, may be viewed as essentially conventional and thus may be, in a sense, arbitrary in the specific form they take. ${ }^{39}$ The key here is that rules are adhered to so long as they are and continue to be accepted by common or convergent preferences among those whom the activity in question involves. When questions arise concerning the interpretation of rules or their analogical development (viz. other rules), principles or other standards of value come into central focus.

In short, standards of judgment and interpretation fulfill an important function for which rules alone simply cannot account. ${ }^{40}$ Moreover, that rules change in response to principles propounded by critical moralists suggests that principles are a part of the rules themselves. For how else can we account for the fact that the critically appraised rules (perhaps in turn adjusted) come to reflect the adjusted moral position that was propounded? ${ }^{41}$

We have seen that a rule differs from an order at least to the extent that it sets a standard of behavior that binds an individual from the internal point of view. Physical power alone cannot suffice. We have also seen from the example of Hart's rule of succession that a ruler must have authority to issue the rule or it cannot be deemed a rule as such. The rule issued, and the rule that authorizes its issuance, point to the two types of social rules whose union, according to Hart, constitutes the heart of the legal system.

37. H.L.A. HART, supra note 8 , at 163.

38. N. MACCORMICK, supra note 33, at 63-65.

39. Id. at 41.

40. For an incisive development of this insight, see R. Dworkin, The Model of Rules $I$, in TAKing Rights Seriously (1978).

41. N. MACCORMICK, supra note 33 , at 54. 
Rules of the first type are primary rules of obligation. These rules impose duties such as those that forbid murder or robbery. Rules of the second type are called secondary rules. They "confer powers, public or private." 42 Secondary rules stipulate how and by whom primary rules may be formed, recognized, modified or replaced. Rules about forming contracts, for example, are secondary rules because they stipulate how specific rules governing particular legal obligations come into existence or are changed. ${ }^{43}$

According to Hart, primitive communities only have primary rules. They are binding because members of the group through its social practices accept the rules as standards of behavior. A society of this kind maintains a set of separate standards which must be accepted by a majority, otherwise those members who reject the rules would have too little social pressure to fear deviation. ${ }^{44}$

Such a society, Hart claims, suffers from three serious defects. First, it lacks any procedure for determining what the rules are or what their precise scope is. The "uncertainty" generated as a result is cured by a secondary rule of recognition. This rule provides specific criteria according to which valid rules may be clearly ascertained. A second defect stems from the primitive society's lack of any means of deliberately adapting their primary rules to changing circumstances. This "static" character of primary rules requires secondary rules of change in order to empower an individual or body of persons to introduce new primary rules and to eliminate old ones. The third defect from which primitive societies suffer stems from the inefficiency of diffuse social pressure by which rules are maintained. Such societies lack any official agency to determine authoritatively the fact of violation of rules and the kind of remedial action that is required. Secondary rules of adjudication are thus necessary to remedy this third defect. ${ }^{45}$

We have noted that according to the two minimum conditions which Hart deems necessary and sufficient to the existence of a mature legal system primary rules must be obeyed by citizens and secondary rules must be accepted by officials. It follows that if the distinction between the two rules breaks down the two minimum conditions may not be fulfilled. There is reason to suggest that the distinction does in fact break down.

42. H.L.A. HART, supra note 8 , at 79 .

43. See id. at 94 .

44. Id. at 89 .

45. Id. at 89-91. 
Hart's understatement of the role of standards and principles in the legal system has already been noted. Additional difficulties also arise due to serious ambiguities in the way Hart defines primary and secondary rules. For example, on the one hand, Hart distinguishes between those rules which lay down categorical requirements (duties or obligations) and those that confer power. On the other hand, he states that secondary rules can all be said to be on a different level from primary rules, for they are "parasitic upon" or "about" such rules. ${ }^{46}$ However, many secondary power-conferring rules do not concern primary rules, especially those that confer powers on private individuals. Moreover, the rule of recognition, which specifies the criteria for legal validity, need not be a power-conferring rule at all. Rather, it may be described as determinative of a source of law. Accordingly, it does not necessarily give power to someone to legislate. That power derives from the rules that Hart calls rules of change. ${ }^{47}$

Further, secondary rules of power at times seem to function not as power-conferring rules but rather as duty-imposing rules. For example, Hart claims that officials such as judges must accept rules of recognition and abide by the dictates of the internal point of view regarding a "public, common standard of correct judicial decision, and not as something each judge merely obeys for his own part only." 48 In other words, the rule of recognition may impose duties upon officials.

From the above it may be argued that Hart's two minimum conditions concerning primary and secondary rules are neither necessary nor sufficient for the existence of a legal system. They are insufficient because they fail to account for the important role principles and other standards play in the interpretation and judgment of rules. Nor can they explain the critical process by which rules are adjusted and, in the process, come to embody those moral standards which were critically propounded. In addition, the serious inconsistencies and ambiguities in Hart's distinctions between primary and secondary rules make doubtful their current viability as the necessary criteria which Hart's minimum conditions require. The following observations further reinforce this conclusion.

So far we have seen that Hart's union of primary and secondary rules maintains the legal positivist position by providing criteria for

46. Id. at 78-79. See also Payne, supra note 22 , at 300; N. MACCoRmick, supra note 33 , at 107 .

47. Payne, supra note 22 , at 315 .

48. H.L.A. HART, supra note 8, at 112. 
verification (based upon rules of recognition) according to which valid laws may be ascertained. On this account, primary rules may be accepted simply as valid based on the applicable rules of recognition. Yet, Hart also maintains that social rules are accepted from the internal point of view as normative standards of conduct. Several difficulties emerge here.

To begin with, as already noted, Hart only requires citizens to obey primary rules, not to accept them. For their part, officials are required only to accept secondary rules. Thus, it would appear that Hart requires no one to accept primary rules. But, as Payne points out, $^{49}$ if this is so, how can they be considered social rules in the first place (since the prerequisite for such rules is their acceptance by at least some social group members in accordance with the internal viewpoint)? And if they cannot, how can they be deemed necessary for the existence of the legal system?

A proposed solution to this difficulty is that because rules of recognition accepted by officials establish valid primary rules, members of the society are "committed to the acceptance in advance of [such] general classes of rule, marked out by general criteria of validity." ${ }^{0}$ It may also be argued that whether or not anyone is required to accept the primary rules is irrelevant since accepted secondary rules of change will empower officials to introduce new primary rules which citizens also are committed in advance to accept. ${ }^{51}$

This response is hardly dispositive of the difficulties it must address. For one thing, citizen acceptance of primary rules in advance of their being promulgated (based on official acceptance of rules of recognition and change) cannot be squared with Hart's two minimum criteria which plainly do not require such acceptance. Thus, Hart must either alter his minimum criteria to require citizens to accept primary rules, or his notion of rules of obligation (as social rules) may need to be rethought. In any event, the notion of acceptance in advance may be challenged in light of the coercive obligatoriness of the official "authority" to which citizens may be "obliged" to submit. It is here where the issue of legitimate power comes to the fore. Indeed, I will contend that so long as citizens are required merely to obey primary rules, that obedience may not necessarily extend beyond coercive obligation. Yet, it is precisely this goal that characterizes Hart's efforts to supplant the Austinian model of law as command backed by threats.

49. Payne, supra note 22 , at 310 .

50. See H.L.A. HART, supra note 8, at 229. See also Payne, supra note 22, at $310-11$.

51. Payne, supra note 22 , at 315 . 
Given official acceptance of secondary rules, nothing in Hart's typology of rules precludes officials from promulgating rules based on official self-interest alone. As Hart makes clear, acceptance may be founded upon many different considerations, including calculation of long-term interests. ${ }^{52}$ Notably, social rules are not necessarily moral rules. Indeed, they may be accepted or rejected on moral grounds. But an official rule based on self-interest is neither necessary nor sufficient for de facto authority. It is not necessary because cittzens could conceivably accept official rules on moral grounds. It is not sufficient because self-interested obedience does not necessarily generate the kind of obedience that is distinctive of de facto authority (i.e., trust in official rules as "right," as opposed to obedience based on fear).

Thus, since officials may rule with de jure authority founded on coercive tactics in their own, but not the majority of citizens' interests, their rule need not receive other than coerced obedience. Deprived of de facto authority the legal system will operate in the absence of legitimate power. Austin's "gunman writ large" has not necessarily been surpassed.

Finally, a circularity that runs through Hart's analysis regarding the officials' acceptance of secondary rules may be noted. Although I will state the circularity here, whether or not it can be resolved within the framework of Hart's concept of law poses a question that can be addressed fully only in the next section, where Hart's minimum content of natural law will be examined.

Hart argues that the social (secondary) rule imposes a legal obligation upon officials based on the behavior and expectations of other officials in the same legal system. What this fails to explain is the reason or reasons why a particular obligation (or primary rule) withdraws one action from the range of an individual's free choice but not another. ${ }^{53}$ The issue of "natural necessity" is implicated here and thus will require our fuller attention in the next section.

It has been suggested that Hart's notion of the internal viewpoint is the key to his concept of law. It permits him to retain external observations about the validity of law (based upon accepted rules of recognition) while also accounting for normative statements that reflect the internal viewpoint of those who accept social rules. By charting a middle way between untestable moral obligation on the one hand, and clear, but coercive obligation on the other, Hart's concept of the modern legal system aims to escape the dual evils of law

52. H.L.A. HART, supra note 8 , at $112,198-99$.

53. See Hoffmaster, supra note 7, at 1214-15. 
as command backed by threats and law as wholly internalized (moral) sanctions. Instead, however, we have uncovered so far a typology of rules that is deeply inconsistent, and a legal system generated by the union of Hart's two rules that fails to ensure that coercive obligation will be avoided.

If there is a way out of this difficulty for Hart, it may be said to rest with the normative standards which the internal viewpoint embraces. If there is a minimum normative content that exists by "natural necessity" in all societies, as Hart claims, then Kelsen's archpositivist view that law can have any content can be overcome. Moreover, if "natural necessity" can explain the ordinary citizen's acceptance of (or, in Shiner's phrase, "acquiescence to") the fundamental rules of recognition, as Shiner claims it can, ${ }^{54}$ then de facto authority may be established - and along with it legitimate power or authority.

Underlying these issues is the previously noted question concerning what I claim is a circularity in Hart's thinking with respect to official acceptance of secondary rules. The difficulty may be put in the following way. The rule of recognition imposes legal obligations on officials of the system but is not itself valid (i.e., there are no ulterior rules validating this type of secondary rule).$^{55}$ Thus, the principle that legal validity establishes legal obligation cannot explain the legal obligations that secondary rules impose. But if this is so, on what basis is official restraint upon individual freedom justified? It is with these issues in mind that I turn now to Hart's notion of the minimum content of natural law.

\section{Hart's Minimum Content of Natural Law}

In The Concept of Law Hart expressly relies upon three kinds of statements. ${ }^{56}$ If his typology of rules encompasses two kinds of statements, ordinary statements of fact and definitions, it is in his account of natural law where we encounter the third, namely, contingent statements. Hart describes the latter as statements "the truth of which is contingent on human beings and the world they live in retaining the salient features which they have." ${ }^{57}$ It is with contingent

54. Shiner, Hart and Hobbes, 22 WM. \& MARY L. Rev. 201, 223 (1980).

55. Hart describes rules of recognition as "ultimate" secondary rules. This means that they provide the criteria by which the validity of other rules of the system is assessed. See H.L.A. HART, supra note 8 , at 102. The other secondary (nonultimate) rules are rules of adjudication and change. See supra text accompanying notes $43-45$.

56. H.L.A. HART, supra note 8, at 195.

57. Id. 
statements that Hart aims to generate the minimum content of natural law. This content, Hart claims, forms an essential part of the framework of any complex society's form of life.

Hart's basic argument for the minimum content of natural law is simply that "without such a content law and morals could not forward the minimum purpose of survival which humans have in associating with each other." ${ }^{\circ 8}$ Given survival as the fundamental aim of humans "[r]eflection on some very obvious generalizations - indeed truisms - concerning human nature and the world in which men live, show that as long as these hold good, there are certain rules of conduct which any social organization must contain if it is to be viable." 59 The truisms in question consist in the "obvious" observations that humans are vulnerable to bodily harm; they are approximately equal in strength and intelligence; they have limited altruism and thus are neither angels nor devils; they have limited understanding and strength of will; and that limited resources exist in the world. Given this reality concerning humans and the world, according to Hart it is a "natural necessity" that there be sanctions to ensure the minimum forms of protection for persons, property and promises. ${ }^{60}$

In light of this descriptive (sociological) approach to natural law, I now turn to the question of whether Hart's minimum content accounts for official de facto authority by providing a justification for citizens voluntarily to accept official rule. Preliminarily, several initial questions need be addressed. First, is the minimum content of natural law as essential as Hart says it is? With one minor qualification I submit that it is. I will pursue the qualification first.

Earlier we noted that Hart's emphasis upon social rules parallels his understatement of principles and other normative standards which do not function as rules. Following MacCormick, I distinguished rules from standards by pointing out an element of arbitrariness in the former that stemmed from their conventionality; that is, rules are accepted as rules so long as they are, and continue to be, actually preferred in practice. Standards, by contrast, not only lack such arbitrariness, but they also do not function in the same cut and dried fashion as rules.

It may be concluded from this analysis that the minimum content of natural law need not consist of primary rules, as Hart claims,

58. Id. at 189 .

59. Id. at 188 .

60. Id. at $188-89$. 
but rather of primary shared standards. In any event, the fact remains that absent some such standards or rules a mode of coercion or pressure to conformity to contain individual aggression could not be arrived at. As Hart puts it:

[Sanctions serve as] a guarantee that those who would voluntarily obey shall not be sacrificed to those who would not.

To obey, without this, would risk going to the wall. ${ }^{61}$

The key sentence to note is the one that follows immediately after the above-quoted passage: "Given this standing danger, what reason demands is voluntary cooperation in a coercive system." ${ }^{2}$

Clearly, the element of volition is crucial if Hart's notion of "acceptance" is to be maintained. But does volition here ensure the kind of acceptance upon which legitimate power depends? I contend it does not. If I am right, official acceptance of the minimum content of natural law fails to provide adequate justification for constraining the range of individual freedom beyond the Hobbesian model of coercive obligation.

Hart's truisms may require voluntary submission to sanctions, but the Hobbesian power-based system of order (rooted in positive justice alone) requires no less. I contend that Hart's legal system may prompt general submission to a system of coercive rules of obligation, promulgated by wholly self-interested officials, without violating Hart's minimum content of natural law.

The aim of peaceable order which underpins Hobbesian civil society - by which the aim of survival is assured-is the rule of law backed by force. ${ }^{63}$ It may be suggested, however, that sanctions constitute a formal prerequisite to any system of peaceable order, but do not guarantee any specific content beyond the maintenance of that order. It is not surprising, therefore, to find Kelsen in agreement with Hart regarding survival as the fundamental aim underlying the legal system.

According to Professor Shiner, the internal viewpoint sets Hart's concept of the legal system apart from Hobbes' ${ }^{64}$ As we have seen, however, and as Shiner ultimately concedes, it is precisely the internal viewpoint that is not ensured by Hart's typology of rules with

61. Id. at 193.

62. Id.

63. T. HoBbes, supra note 4 , at $84-87$.

64. Shiner, supra note 54 , at 217. 
respect to citizens' general obedience to primary rules of obligation. Shiner's attempt to derive general acceptance from Hart's notion of "natural necessity" by some unspecified "metaphysical" grounding is his way out of this difficulty. A little later on, I will examine, and find wanting, Shiner's proposal. Before that, however, a prior issue must be addressed.

The preceding analysis treats Hart's minimum content as a prerequisite to formal, but not necessarily moral order. If a minimum moral content existed, as Hart claims, not only would officials be entitled to obedience, but also Kelsen's claim that law may have any content would be repudiated. I contend, however, that Hart's minimum content presupposes a compelling (imperative) norm that at most is "premoral"; it does not necessarily generate moral content.

Hoffmaster has claimed that the minimum content of natural law may constitute a "principle of fairness." ${ }^{65} \mathrm{He}$ argues that mutual forebearance and compromise are at the "base of both legal and moral obligation" (which comprise Hart's minimum content of natural law). Hoffmaster acknowledges, as he must, that this "ground of moral right . . . is not made explicit by Hart." However, he insists that it is suggested by Hart's "worry about people trying to obtain the advantages of the system without accepting the burdens." ${ }^{\circ 6}$

I maintain that the "moral right" to which Hoffmaster refers cannot be deemed a necessary attribute of Hart's minimum content. My argument turns, in part, upon what has been dubbed the "imperative fallacy." It is a variation of what G.E. Moore called the "naturalistic fallacy" ${ }^{67}$ and stems originally from the work of Hume, who claimed that "ought" statements cannot be derived from "is" statements. ${ }^{68}$

H.J. McCloskey has observed that "the whole point, the thing chiefly involved in adopting the moral standpoint, is a willingness to subordinate our own interests to what is right and obligatory." 69

65. Hoffmaster, supra note 7 , at 1316.

66. Id. at 1317 .

67. G.E. Moore, Principia Ethica 9-11 (1903).

68. D. Hume, A Treatise on Human Nature 521 (E. Mossner ed. 1969).

69. H. McCloskey, Meta-Ethics and Normative Ethics 77 (1969). See also J.S. Mill, Utilitarianism 60 (O. Piest ed. 1957); MacCormick, A Moralistic Case for A-Moralistic Law?, 20 VAL. U.L. REv. 1, 12 (1985) ("It is of the essence of a moral life that it consists in and rests on the free, that is, the uncoerced choice of right ways of acting for their own sake or for the sake of their consequences viewed in a disinterested way."). 
Notably, this is consistent with Hart's notion of the internal viewpoint. As we have seen, the internal viewpoint manifests the adoption of a normative standard that generates legitimate ("justifiable") criticism regarding one's own and other's behavior. This viewpoint may be said either to embody or at least to presuppose active commitment to a shared standard of conduct or underlying value. The key to the internal viewpoint, and consequently to Hart's notion of social rules in general, lies in its stark contrast with the externality of sanctions that accompany Austinian "commands." The Hartian critical reflective attitude generates an internal sanction that informs judgment. It is right in itself and appeals to an individual's conscience in addition to cruder threats of punishment or social ostracism. ${ }^{70}$

As MacCormick has argued, a norm that guides judgment and underpins human action which is susceptible of no ulterior underlying reason concerning the approval of, or preference for certain conduct, may be described as "good in itself" or as an ultimate, as distinct from a merely instrumental or derivative, value. ${ }^{71}$ Ultimate values cannot proceed by way of demonstration or proof. ${ }^{72}$ The acceptance of social rules, then, may be described as the voluntary endorsement of some normative standard or value that serves as a basis for judgment.

Granting the validity of the above analysis, Hart's notion of survival may be described as an ultimate value. It provides a reason for fundamental rules which, taken together with certain truisms about humans and the world, constitute the minimum content of natural law. Upon closer scrutiny, however, survival lacks essential features of morality.

Most significantly, survival is not distinguishable from a merely instrumental or derivative value; it does not function as a basis for concern towards the other, nor does it appeal to individual conscience. Indeed, as Hart's phrase "natural necessity" suggests, survival and the minimum content can generate imperative, but not prescriptive statements. Survival may give rise to the command "Thou shalt not kill," but "Thou shalt not kill" does not mean the same as "You ought

70. Hart notes that those who accept and use rules from the internal viewpoint ("as guides to the conduct of social life") are normally the majority. By contrast, the tacit endorser of norms assumes the status of an outsider within society. See H.L.A. HART, supra note 8 , at 87-88; supra text accompanying note 35 .

71. N. MACCoRmick, supra note 33 , at 48.

72. Id. Cf. J.S. MILL, supra note 69 , at 4 (quote found on the title page of this article). 
not to kill."73 As MacCormick states, "it is by no means evident that 'ought' is derivable from 'shall' or 'shall' from 'ought'."74 Thus a rule or command does not necessarily give rise to a prescription-as Kelsen and Hare inccrrectly thought. ${ }^{75}$

That survival fails as a moral "ought" may be demonstrated by the following. Since it lacks a principle that can be universally applied to others, one may assert that survival "justifies" a convict's murder of his executioner, or the fleeing of a soldier from battle (after having been conscripted to fight in a presumably "just" war). Notably, surviving or not surviving is not necessarily determined in terms of "right" or "wrong." No appeal to a value or the right of the other to live is made. In short, there is no basis here for disinterest or appeal to conscience. It may be said, then, that survival is consistent with pre-moral reflection, and may even be a prerequisite for moral reflection. But it does not of itself necessarily manifest moral content.

Notably, Hobbes accepted these consequences (murder and fleeing from battle) as logically consistent with survival as a fundamental social aim..$^{76}$ It is hardly plausible, however, that conscience, a chief attribute of the internal viewpoint, could endorse such actions.

To summarize the argument, as a matter of observation we may agree with Hart that people universally disapprove of murder. Sociologically speaking, this observation may be susceptible of verification or disproof by means of empirical research. But if we take a step further, and ask the meaning of the statement "murder is morally wrong," we find no provision within Hart's analysis for a response.

73. Hart characterizes such commands as the "imperative mood." H.L.A. HART, supra note 8 , at 18.

74. MacCormick, Legal Obligation and the Imperative Fallacy, in OXFoRD EsSAYS IN JURISPRUDENCE 100 (A. Simpson 2d ed. 1973).

75. Id. at 109. See H. McCloskey, supra note 69 , at 66-80.

76. T. Hob8es, supra note 4, at 142-43. See also Krygier, The Concept of Law and Social Theory, 2 Oxford J. Legal Studies 155, 180 (1982):

[Q]uite apart from the fact that Hart has chosen to rest with "truisms" about the human condition, these are truisms of a specifically individualist, pre-sociological kind. . . . Certainly, there are elements common to law and morality in all societies, such as incest, taboos, rules regarding kinship, marriage and descent, the existence of which needs to be explained. A methodological individualist might explain such phenomena in terms of universal individual purposes other than survival; a functionalist sociologist might identify "social functions" which are necessary if certain forms of social organization are to persist despite the passing of individuals. In either case, the minimum content of natural law is unlikely to survive unscathed. 
Put simply, it may be descriptively accurate to say people generally disapprove of murder, but from the fact that people generally believe murder is wrong, the conclusion does not necessarily follow that it is wrong to kill. Indeed, to draw such a conclusion would be to indulge in the naturalistic fallacy of deriving ought from is. Thus, there seems to be no analytical or empirical means within Hart's approach to support truth claims about the wrongness of murder (or, for that matter, the rightness of survival).

It is possible to rejoin that Hart did not intend to make truth claims about morality. But the fact remains that absent such claims Hart's reliance upon a minimum "moral" content of the law remains dubious. He cannot plausibly identify a minimum moral order (and thus provide a minimum "ought" content for the law) simply by describing social conventions (the "is")." Nor will specific reference to "survival" remedy the problem. As already noted, the felt need to survive represents a pre-moral, self-interested attitude. This attitude-rooted in fear (of death) or desire (for security)-need make no appeal to conscience or moral principle. Indeed, as Hobbes has shown, the desire to survive (in Hobbes' terms, the desire to escape the "natural state" of war of all against all) readily serves to justify abandoning the safeguards that moral principles provide against absolute state power and rule by coercion.

Based on the foregoing analysis, I submit that the minimum content of natural law, as a formal pre-requisite to peaceable order (the existence of sanctions), reflects a pre-moral attitude that cannot ground de jure authority (the right to make rules) in de facto authority (the right to be obeyed). In short, it fails to preclude coercive obligation. Accordingly, Hoffmaster's claim that the minimum content involves a "moral right" or "principle of fairness" must be rejected.

If this conclusion is correct, Hart's descriptive sociology fails to break free of the problem of circularity that was discovered to underlie his description of official acceptance of secondary rules. Acceptance

77. As recent history has taught, the legality of Nazi atrocities hardly conceals the immorality of such social practices. See A TESTAMENT of Hope: THE Essential Writings of Martin LUTher KING, JR. 294-95 (J. Washington ed. 1986). It is in this sense that $I$ emphasize the need to take active responsibility for normative commitment. A meaningful statement about social morality presupposes active belief. The "ought" is not a mere epiphenomenon. To the contrary, it has its own ontological status; it signals a way of being and speaking among others which is uncapturable by description alone. Indeed, it is this very insight that characterizes the advance beyond pure legal positivism that Hart's "internal viewpoint" allows. See also L. Fuller, The MORality of THE LAW 186 (1969) ("Communication is something more than a means of staying alive. It is a way of being alive."). 
as a matter of social practice fails necessarily to yield a justification for obedience beyond coercive obligation. I have also suggested that the minimum content of natural law offers no solution to this difficulty. Accordingly, Hart's concept of the legal system cannot guarantee an escape from Kelsen's contention that law may have any content (given its validity) or from Austin's model of coercive obligation.

The key to legitimate authority may remain embedded in Hart's notion of the internal viewpoint and the normative standards or values that that viewpoint embraces. Yet, Hart's staunch commitment to an exclusively descriptive approach deprives him of the means of possessing it. Thus, he remains the prisoner of a circularity engendered by the restrictive premises upon which his thinking relies.

Shiner, while recognizing Hart's notion of the internal viewpoint as the key to escaping from Hobbes' de facto power-based system, insists that Hart's descriptive analysis of legal obligation is sufficient. ${ }^{78}$ He concedes that Hart's approach requires a "metaphysical grounding" which, according to Shiner, Hart "has neither supplied nor seen the need for." " 9 Unfortunately, the nature of the metaphysics involved remains unclear since Shiner leaves that "for another time." Metaphysics aside, Shiner goes on to assume away the problem: "the existence of legitimate legal authority is internal to man as social animal." 81

The conceptual bridge to this assumption seems to be based upon Shiner's view that Hart's notion of acceptance needs to be broadened. Accordingly, Shiner proposes that although citizens do not actually accept rules of recognition, they "acquiesce" to them. While not equivalent, acquiescence apparently is enough acceptance to give officials the right to be obeyed.$^{82}$ But Shiner's notion of acquiescence is far too slender a reed to bear the weight of de facto authority. Indeed, it misses the point of Hart's most significant contribution to jurisprudential thinking by diluting beyond recognition, if not wholly abandoning, the cognitive and volitional elements that give the internal viewpoint, and thus Hartian social rules in general, the crucial place they hold in Hart's legal system. It is also unconvincing.

It seems plausible that acquiescence of the kind Shiner suggests may be obtained by a ruler unaccompanied by general trust or

78. Shiner, supra note 54, at 203.

79. Id.

80. Id. at 224 .

81. Id. at 225 .

82. Id. at 223 . 
acknowledgement of his right to rule. The Shah of Iran and Nicaragua's Somoza come to mind as recent historical examples of leaders who apparently received general acquiescence until revolutionary action overthrew them. Prior obedience surely was not a sign of endorsement of official "authority." 83

In short, absent the metaphysical legwork which Shiner admits is necessary, but declines to provide, his suggestions that general citizen "acquiesence" is "inevitable" or "internal to what it is to be a social being" 84 do not wield explanatory or persuasive force. What they do achieve, however, is to once again bring into focus the limitation that I believe may be inherent in the descriptive approach itself. I submit that it is this limitation that forces Shiner's unwitting concession to ignorance in his statement that legal obligation simply "has to be accepted as a given." 85 This may "leave legal obligation as it is," but it hardly tells us much about what obligation is, or why it constrains the range of individual freedom by imposing one rule of obligation rather than another.

In the remainder of this section I propose a way out of what may be called the descriptive dilemma. My proposal accepts Shiner's critical observation that Hart's descriptive approach reveals "metaphysically deep aspects ... of the natural history of human beings." ${ }^{86}$ But I deny the value of this observation in the absence of a non-descriptive viewpoint. The viewpoint I advocate requires a normative grammar grounded in deliberation and discourse, not "necessity" - natural or otherwise. ${ }^{87}$

83. Former Philippine President Ferdinand Marcos' attempt to rule despite the public's refusal to accept his authority adds a more recent example of power without legitimacy. See N.Y. Times, Feb. 26, 1986, at 4, col. 4. Ten days prior to Marcos' departure from the Philippines, the Catholic Bishops' Conference stated:

According to moral principles, a government that assumes power through fraudulent means has no moral basis. For such an access to power is tantamount to a forcible seizure and cannot command the allegiance of the citizenry. The most we can say about such a government is that it is a government in possession of power.

Id.

See also Sunstein, Naked Preferences and the Constitution, 84 Colum. L. REv. $1689,1727-28$ (1984) ("Raw political power is not a legitimate basis for government action. ...").

84. Shiner, supra note 54 , at 223 . For a similarly critical response to Shiner's analysis, see Payne, Law Based on Accepted Authority, 23 WM. \& MARY L. REv. 501 (1982).

85. Shiner, supra note 54, at 225.

86. Id.

87. See Gibbard, supra note 36 , at 19 :

Normative discussion consists of taking positions. . . Consensus may 
The notion of legitimacy this suggests is one that presupposes a mode of co-existence that in some respects may be characterized as phenomenological. That is, man is seen as fundamental interrelatedness with things and others around him. ${ }^{88}$ From this viewpoint, justice is conceived in terms of the individual's willingness to act in accordance with the demands of the rights and duties of others. ${ }^{89}$

In my argument, I also rely, in part, upon Mill's notion of "founding principles" at the core of obedience. ${ }^{90} \mathrm{I}$ contend that this may serve as a justifiable basis for de facto authority. By returning, then, to the notion of ultimate values and the voluntary acceptance of founding principles, Hart's crucial insight concerning the internal viewpoint may be retained-and perhaps even strengthened. For here a way to ensure legitimate authority may be uncovered.

According to Mill, the "internal sanction," when "disinterested and connecting itself with the pure idea of duty," is the "essence of conscience." Mill identifies the deep foundation upon which this notion of duty rests. He calls it the "first principle of morals." ${ }^{92}$ For my purpose here, I shall treat this notion as interchangeable with MacCormick's term "ultimate value." Ultimate values, then, (unlike Hobbesian positive justice) imply something which "it is not only right to do, and wrong not to do, but which some individual person can claim

then be reached by a mechanism that is incipiently socratic. Discussants hold each other to consistency in their positions, and thus force each other to shift positions by exposing inconsistency. A person, then, must take positions in order to engage in normative discussion responsibly, and in doing so, he exposes himself to pressures toward consistency. To accept a norm, we might say is to be disposed to avow it in unconstrained normative discussion as a result of the workings of demands for consistency in the positions one takes in normative discussion.

88. W. LUIJPEN, supra note 13, at 145-54. "The world cannot be separated from the subject ... and the subject is inseparable from the world, that is, a world which he projects himself." Id. at $142 \mathrm{n} .105$ (citing M. MERLEAU-PonTY, PHÉNOMÉNologie DE LA PERCEPTION 491 (1945)); Because there are no "given norms" . . the decision on which the legal order depends lies wholly in man's freedom. ..." Id. at 213 (citing E. Fechner, Rechtsphilosophie, Soziologie und MEtaphysiK des Rechts 250-53 (1956).

Reference may also be made here to recent psychological analyses that add to the conceptual framework of Freudian structural theory. The drive to satisfy or thwart impulses (Freud, [Hobbes]) is supplemented by a drive toward object relationship. See, e.g., Alonso \& Rutan, The Impact of Object Relations Theory on Psychodynamic Group Relations, 141 Am. J. Psychiatry 1376, 1376-80 (1980). See also the developmental psychologies of Jean Piaget and Lawrence Kohlberg.

89. W. LUIJPEN, supra note 13 , at 144, 180-81.

90. J.S. MiLL, supra note 69 , at $32,36,73,76$.

91. Id. at 36 .

92. Id. at 78. For Mill this involves the "greatest happiness principle" whereby each individual's "happiness" is counted for exactly as much as another's. $I d$. at 76. 
from us as his moral right." ${ }^{93}$ The articulation of general principles about conduct serves to maintain the coherence, and promote the realization of ultimate values.

Normative standards endorsed by the critical reflective attitude of the internal viewpoint may be traced to ultimate values, that is, values beyond which there is no ulterior reason or justification for action or non-action. The rationality of principles generated by such standards may be challenged to the extent that they are consistent or inconsistent with such values. Ultimate values cannot be fully accounted for by description alone. Also, the hermeneutic approach that yields understanding of values without active commitment is insufficient. Values require actual endorsement. ${ }^{94}$ While social practice may evidence value acceptance, it does not constitute it. For example, a conventional practice that gives rise to expectations of the sort that are considered good grounds for asserting a particular duty cannot explain the moral basis for respecting such expectations. ${ }^{95}$ As Dworkin points out, the moral foundation for judgments consists in the principle that one ought not to disappoint expectations that are reasonably created and reasonably held. ${ }^{96}$ Thus, Hart's notion of social rules embodies a value endorsement that justifies fulfilling obligations derived from social conventions. Those conventions, however, cannot explain the value that generates the principled basis for judging.

Coercive obligation devalues the individual's moral intelligence and dignity as an individual. ${ }^{97}$ Dignity and moral intelligence presuppose the ability of an individual rationally to choose ultimate values as his own ideals and bases for obedience. Locke's notion of the right to property and our own constitutional enshrinement of the right to life, liberty and the pursuit of happiness are illustrative of shared ultimate values. These values provide reasons for trusting authority with power; they entitle rulers to be obeyed. In short, they provide de facto authority. Thus the legitimacy of power is rooted in a shared consensus among citizens regarding ultimate values.

In this way, Hart's descriptive analysis of legal obligation is preserved to the extent that normative discourse, as a phenomenon of internal statements, exists as a social practice. However, we must

93. Id. at 62 .

94. Cf. Aristotle, supra note 3 , at 537. Concerning virtue, Aristotle states: "[I]t is not enough to know, but we must try to have and use it, or try any other way there may be of becoming good."

95. Hoffmaster, supra note 7 , at 1323.

96. Dworkin, Social Rules and Legal Theory, 81 YALE LAw J. 855, 867 (1972).

97. See J.S. MILL, supra note 69 , at 13. 
go beyond the minimum conditions that constitute Hart's concept of the legal system. The requirements of legitimate power or authority make it encumbent upon officials as well as citizens in general to engage in committed valuational discourse so that ultimate values may enjoy continued consensus. ${ }^{98}$ This requirement generates the need for a normative grammar that extends beyond statements of fact, definitions or contingent statements. ${ }^{99}$ Actual endorsement cannot be captured by descriptive hermeneutics alone. As Vico once wrote, in history we are actors, in the sciences mere spectators. ${ }^{100}$ It is this suggestive observation that points to a Cartesian bias underlying Hart's descriptive sociology and conceptual typology of rules that keeps him within the confines of a circle-engendering (scientistic) descriptive viewpoint. ${ }^{101}$

The beginnings of a middle way between moral obligation and coercive obligation have been forged by Hart. His notion of legal obligation eschews the extremes of Rousseau's utopian notion of wholly internal sanctions and Hobbes' rather cynical idea regarding wholly external sanctions. Instead, Hart roots obligation in legitimate authority. I have suggested that in order to ensure this advance an additional step needs to be taken. Hart's compelling norm alone, (what I have described as the imperative, pre-moral content of Hart's natural law), cannot adequately ground legal obligation. I submit that, in addition, general acceptance of discursive founding principles or ultimate values is required. This step, sanctioned by the inner authority of

98. See MacCormick, supra note 69, at 13. The majority's "current truth" is an insufficient test for truth per se; "free debate" among rival views is "essential to test the strengths and weaknesses of moral and other theses and systems of thought."

99. See J. Habermas, Legitimation Crisis 88-91 (1973); J. Habermas, ComMUNICATION AND THE EvOLUTION OF SOCIETY 34-68 (1979).

100. I. Berlin, Vico and Herder 67 (1976).

101. The debate surrounding the descriptive ("neutral") observation of phenomena versus active ("committed") interpretation remains lively in both contemporary social theory and legal philosophy. See, e.g., Fletcher, Two Modes of Legal Thought, 90 YALE L.J. 970, 987-89 (1981) (affirming the merits of "committed argument" in the face of our cultural bias toward seeing law as an "empirical" science involving "detached observation"). Fletcher states: "In the mode of committed argument, we seek both to learn from the conflict in case law and to exercise responsibility for the ongoing refinement of the legal system. . . We have no choice but to mediate between the indifference of neutrality and the distortion of argument." Id. at 1003; R. Bernstein, Beyond Objectivism and Relativism 45 (1983) (describing H.G. Gadamer's battle against the intrusion of method into hermeneutics and S. Wolin's attack on "methodism"). Bernstein states: "Method is not innocent or neutral. It not only presupposes an understanding of what constitutes an understanding of political life; it has become a powerful factor in shaping (or rather misshaping) human life in the modern world." 
conscience, preserves intact the key feature of the internal viewpoint, namely, the voluntary endorsement of normative statements.

Cognizant of the need for some metaphysical grounding, and of the deliberations characteristic of practical reason, this conclusion may appear to capture an Aristotelian echo. Indeed, it suggests that ethics (in its original sense as the nature of human character) ${ }^{102}$ remains the foundation for the legitimation of authority in the modern legal system.

\section{CONCLUSION}

In conclusion, I submit that Hart's concept of law is more open than either his typology of rules or his minimum content of natural law suggest. First, the two minimum conditions for the existence of the legal system cannot be deemed necessary and sufficient in their current form. Hart's understatement of the role of standards and principles, and the deep inconsistencies in his definitions of primary and secondary rules necessitate substantial revision in his typological analysis. Second, Hart's attempt to ground normative standards in the minimum content of natural law (a) fails to guarantee any minimum moral content of rules (and thus leaves intact Kelsen's claim that law may have any content) and (b) fails to ensure that the legal system will eschew coercive obligation (and thus does not necessarily supplant the Hobbesian reliance upon externally enforced laws).

To overcome some of these obstacles, I have suggested that the compelling (or imperative/pre-moral) norm that underlies Hart's minimum content of natural law must be supplemented by committed endorsement of discursive founding principles or ultimate values. Thus Shiner's unrealistic notion of general citizen aquiescence to secondary rules may be replaced by what I believe to be a more plausible account, namely, general acceptance of ultimate values. Contingent statements thus are supplemented by normative statements that generate consensus. Once the core of obedience is principled in the manner I have suggested, the ground for de facto authority is established. This authority in conjunction with the de jure authority established by secondary rules of recognition, adjudication and change, serve to ensure the legitimate authority of the legal system.

102. This notion of "character" ( $q u a$ ethos) seems also to comport with Alasdair MacIntyre's understanding. A. MacintYre, After Virtue 29 (1981). "A character is an object of regard by the members of the culture generally or by some significant segment of them. He furnishes them with a cultural and moral ideal. ... The character morally legitimates a mode of social existence." Id.

According to MacIntyre, it is through character that moral and metaphysical ideals and theories assume an embodied existence in the social world. Based on the normative grammar I am proposing here, one might say that it is by choosing and characterizing character that one engages in moral activity. 
The notion of legitimation that I have drawn from Hart's internal viewpoint presupposes the dignity and moral intelligence of the individual. I contend that Austin's coercive obligation and Hart's minimum content of natural law do not. In accordance with this notion of legitimation, the ends of citizens are rooted not in some idea of "natural necessity," but in freely chosen ultimate values. ${ }^{103}$ As Hart's descriptive theory might suggest, preferred values are those generally shared in society. However, contrary to Hart's descriptive approach, I submit that social practice, although indicative of consensus, is irreducible to the ultimate values upon which consensus (and therefore legitimate authority) is based.

Thus, in addition to truisms about man and the world, and beyond the prudential designs humans share, legitimate authority presupposes a minimum "normative reality," intersubjectively recognized, as a justified basis (the source of rightness) for trusting officials (with power). This normative reality is discursively realized; that is, it emerges out of the clash and exchange of views among diverse social groups. ${ }^{104}$ This means that the lay public as well as the legal expert need share in the struggle for consensus on ultimate values. ${ }^{105}$

At the outset of this essay, I suggested that shared value preferences conform to shifting images of self which underlie and sustain the founding principles of the social world. In concluding, I have hinted, albeit in gingerly fashion, that the post-modern image of man casts a wink at Hobbes and his hard, modern vision, and bows to an ethic characteristic of Aristotle.

103. That is, by choosing a people ultimately constructs the reality of their social world and of human nature itself. See P. BERGER \& T. LuCKMANN, supra note 12. See also J. WhITE, supra note 13 , at 275.

104. Since no individual can claim a monopoly on truth and goodness, those who would participate in normative discourse must remain open to the beliefs and values of others. Each participant in the dialogue must be prepared to learn from the dialogue itself. See Gibbard, supra note 36. See also Burt, Constitutional Law and the Teaching of the Parables, 93 YALE L.J. 455, 487 (1984) ("Dialogic engagement provides the means to create mutual meaning on which the rule of law depends."); Cover, Forward: Nomos and Narrative, 97 HARv. L. REv. 4 (1983) ("The challenge presented by the absence of a single 'objective' interpretation is ... the need to maintain a sense of legal meaning despite the destruction of any pretense of superiority of one nomos over another.").

105. Compare H.L.A. HART, supra note 8, at 57-59 (citizens need only obey rules of behavior which are valid according to the system's ultimate criteria of validity; only officials (the "experts of the system") need accept as common critical standards of official behavior rules of recognition-specifying the criteria of legal validity - along with rules of change and adjudication) with THE FEDERALIST No. 28, at 180 (A. Hamilton) (C. Rossiter ed. 1961) ("The obstacles to usurption and the facilities of resistance increase with the increased extent of the state, provided the citizens understand their rights and are disposed to defend them."). 
Valparaiso University Law Review, Vol. 20, No. 3 [1986], Art. 1

https://scholar.valpo.edu/vulr/vol20/iss3/1 